\title{
Rediscovering A Path to Aging in Place: Development of Housing Cooperatives for Rural Elderly
}

\section{Hyunjeong LEE}

Dept. of Housing and Interior Design, Kyunghee University, Seoul, Korea

\begin{abstract}
Profit-keeping behaviors naturally occur in the market to satisfy consumers, and the logic behind it lies in the economies of scale. On the flip side, some commodities transacted in the market are not available or can not be easily acquired unless the demand is high enough. Under this proposition, some consumers rise and find their own solution to meet the services at a reasonable cost or at an adequate level. The commonly adopted way is to establish a cooperative, and it stirs purchasing power by pooling resources and further bargains price and service quality. As a consumer cooperative, housing cooperatives notably found in rural towns enable the elderly to continue independent living. This study is to take a closer look at residential life of the rural elderly in housing cooperatives. Utilizing in-depth focus group interviews with 40 residents in four housing cooperatives, this qualitative research draws main factors affecting the decision to move in, residential assessment, and strengths and weakness of living in a housing cooperative. The primary factor influencing the moving decision is to continue to independent living in a familiar community, and the bottom line is planning ahead. Frailty and bereavement are found to be the leading occasions for them to move. The participants are satisfied with the independent living arrangement, and particularly, cited such features as safety and security, elderly-friendly design, common spaces, freedom, social activities and efficient living. Also, it is stated that some cooperative natures such as control over the property and giving a voice on management render positive impacts on the satisfaction with communal living. In spite of all the benefits and strengths, participants face with a public notion that an independent living arrangement like a housing cooperative has never done before in rural towns, so that most people recognize it as part of dependent living arrangements like nursing home.
\end{abstract}

Keywords : Elderly, Residential Life, Rural Areas, Independent Living Arrangement, Cooperative Housing, Aging In Place

\section{INTRODUCTION}

The production and consumption of commodities sustain a community. Not all the commodities often exchanged at the market are not as easily available and accessible in rural areas as in urban areas, and rural people in response to this circumstance pool their own resources and produce a sizable power of the market. Using economies of sale, rural people can acquire the products and services at a reasonable cost, and the approach stimulates organizing cooperatives as a business form. For a variety of reasons, different kinds of cooperatives are formed, and the leading drive to set up a cooperative is to provide serviceatcost. Due to the nature, cooperatives that have been fostering the sustainability of rural

Corresponding Author: Hyunjeong LEE, Assistant Professor Dept. of Housing \& Interior Design, Kyunghee University 1 Hoegi-Dong, Dongdaemun-Gu Seoul 130-701, South Korea Tel: +82 29619192 e-mail: ecohousing@khu.ac.kr

This is an Open Access article distributed under the terms of the Creative Commons Attribution Non-Commercial License (http://creativecommons. org/licenses/by-nc/3.0/) which permits unrestricted non-commercial use, distribution, and reproduction in any medium, provided the original work is properly cited. communities are likely to be sustained in the midst of the market economy in which many business failures are common and occur often. Cooperatives vary with the purposes and are widely found in agricultural business, particularly in rural towns. Although most of rural people including farmers are affiliated with cooperatives in a direct or indirect way, housing cooperatives are rarely known. As the rural areas experience the increasing number of aging population, decent and affordable housing that accommodates the special group poses a prevalent issue to keep the community sustainable. It is often reported that rural people are likely to own a home and live in less expensive but bigger housing than do urban people (Dolbeare, 1999). Considering that rural elderly live in large housing, the housing becomes challenging and demanding as aging progresses. Housing cooperatives centering upon Midwest emerge and are identified as affordable housing for rural elderly. The primary purpose of this study is to examine a housing cooperative as a viable housing solution sustaining rural communities. The specific goals are illustrated as follows: 1) to explore the key factors that influence the decision of rural elderly to move to housing cooperatives: 2) to describe their residential assessment on communal living and 3) to delineate strengths and weaknesses of cooperative living. 


\section{LITERATURE REVIEW}

\section{(1) Cooperative Business}

(1) Definition and distinctions of cooperative business: Generally, a cooperative is defined as a business form owned, democratically controlled and run by members who use commodities that would not be acquired on their own way, and whose benefits are derived and distributed equitably on the basis of use (Frederick, 1997; Meyer, 1999; Kennedy et al., 1995). Cooperatives have similarities and differences from other types of businesses and basic forms of business necessarily need to be understood to find out the distinctions of cooperatives.

The proliferation of numerous businesses in the United States is heavily backed by the free enterprise system that is an economic system allowing individuals to make their own economic decisions(e.g., acquisition of goods, disposal of products and labor, and participation in business structure), being free of government constraints, and being as private profitpotential business(Meyer, 1994). The business system is based upon four fundamental principles freedom of choice, private property rights, profit motive of owners and owner control. Given those, three basic forms of business organizations legitimately exist individually owned business, partnerships, and corporations (Cobia, 1989; Frederick, 1997; Meyer, 1994; US Dept. of Agriculture, Agricultural Cooperative Service, 1993a, 1993b).

A cooperative corporation is a legal entity that provides economic services to its members who are owners and users at reduced costs. In other words, the economic benefits given to members are a business priority, and it is to increase the income of members, improve the quality of services provided, and optimize the use of members' resources. Capital relies on the direct contributions of members like membership fees or sale of stock, agreement with members to withhold a portion of net income based on patronage, or regular assessments of products purchased or sold. Any profit is given back to mainly members in proportion to patronage or possibly reserves, which distinguishes a cooperative from an investorowned business. Also, a cooperative has limited liability, and can exist as long as the business is not terminated. Every member must have one vote, and it is on a basis of democratic control without having nothing to do with the number of shares owned. Due to the distinct features, a cooperative has articles of incorporation, bylaws, policies, and often membership agreement (Frederick, 1999).

(2) Cooperative principles and practices: It is stated that cooperation emerges as early as civilization, and Craftmen's Guild in Middle Ages is a forerunner with some features of cooperative business. Many cooperative businesses have been structured since the first international movement dating back to the $1800 \mathrm{~s}$. The Rochdale Equitable Pioneers' Society was founded in England in 1844, and organized an urban consumer cooperative (Frederick, 1997; Meyer, 1999). As one of the earliest cooperatives, the Rochdale Society consisting of various businessmen purchased supplies and goods and also sold such commodities as food and clothing to people who were not satisfied with products in the urban community. Since then, many kinds of cooperatives have flourished and been a viable part of the economy around the world.

The Rochdale Society drew up a set of practices and policies that became principles of cooperatives, and the Rochdale Principles include open membership, one member one vote, cash trading, membership education, political and religious neutrality, no unusual risk assumption, limitation on the number of shares owned, limited interest on stock, goods sold at regular retail prices, and net margins distributed according to patronage (Frederick, 1997; Meyer, 1999; Parliament, 2000). As one kind of cooperative principle, the Traditional Principles have four tenets, and they are service at cost, financial obligation and benefits proportional to use, and limited return on equity capital, and democratic control. Another type of cooperative principle that is commonly adopted today is Contemporary Principles, and they consist of the three ingredients: the userowner principle, the usercontrol principle, and the userbenefits principle.

Cooperative principles are accompanied by practices many cooperatives follow, and they concern the patronage refund system, limited return on equity capital, and cooperation among cooperatives as well as open membership and continuing member education.

\section{(2) Housing Cooperatives}

(1) Incorporation as a consumer cooperative: As part of the consumer cooperatives, a housing cooperative is defined as a legal organization that is a jointly owned, democratically controlled, notforprofit entity for the purpose of providing members with housing and its services on a continuing basis (Kennedy et al., 1995; US Dept. of Agriculture, Rural Business - Cooperative Service, 1996). It is reported that as of March in 2005, more than 6,400 housing cooperatives in the U.S. serve 1.5 million households (National Cooperative Business Association, 2008). Incorporation of a housing cooperative requires articles of incorporation, bylaws, an occupancy agreement known as proprietary lease which is a legal document between the member and the cooperative, and a subscription agreement that is the initial contract between the prospective member and the cooperative.

It is reported that many features (e.g., a form of ownership, monthly costs, costs at movein, owner's liability, community control, community services, maintenance, tax benefits, management, increases in resale prices, replacement of facilities and equipment, vacancies, moveout/resale) are distinctive according to the housing structure types (e.g., singlefamily home, rental housing, condominium housing and cooperative housing)(National Association of Housing Cooperatives, undated). Cooperative housing is often compared to condominium housing although both of them shares some common features (e.g., common interest ownership, community services, community control, tax benefits, management). Cooperative housing doesn't have personal liability of any individual owner on a cooperative's mortgage but do have liability for share loans. By extension, maintenance in a resident's unit is generally done by the cooperative housing. Also, residents in a cooperative housing are sole owners of the property through a corporation. On the contrary to cooperative housing, condominium housing is similar to singlefamily home in that a owner's responsibility is great in monthly costs, costs at movein, increases in resale prices, vacancies, and moveout/resale.

(2) Governance and stakeholders of cooperatives: Similar to other sorts of cooperatives, housing cooperatives rely on the governing structure consisting of members, the board of directors, the hired manager and employed staff (Kennedy et al., 1995). All the 
members who are residents, users and owners in the cooperative have certain obligations specified by the agreement between the cooperative and its members, and accordingly, they have rights and responsibilities toward the cooperative. In fact, they are expected to help maintain the cooperative in an economically sound fashion. The body running each housing cooperative is the board of directors elected by the members of the cooperative, and contains between 6 and 9 directors. The board plays a key role in operation and management of cooperative housing, and it consists of President, Vice President, Secretary and Treasurer, along with some steering committees. The positions are appointed in the first annual meeting, and certainly members have an opportunity to run for office or to vote for the individuals serving on the board. Managers and staff are hired by the board, and they are supposed to serve members effectively. It is of importance to keep good relationships between the board and the manger, which significantly affects the success of the cooperative.

(3) Cooperative living: Housing cooperatives are available for people with special needs, and the kinds are different to satisfy local needs. Most of the previous studies on cooperative housing heighten urban settings and particularly, affordable housing for lowincome households (Bratt, 1991; Ellenbecker \& White, 1987; Heskin, 1991; Heskin \& Leavitt, 1995; Leavitt \& Saegert, 1990; Miceli et al., 1994; Parliament et al., 1998; Rohe, 1995; Saegert \& Winkel, 1996, 2001; van Ryzin, 1992, 1994; Zimmer, 1977). Only a couple of studies notably focus on housing cooperatives for elderly people in rural areas. Altus and Matthews (1997) conducted a questionnaire survey in a form of postoccupancy evaluation targeted rural elderly people living in cooperative housing, and they found that the respondents were satisfied with their living, and the living had positive effects on their life. Similarly, another study conducted by Nolan (1997) examined the life satisfaction of rural elderly in cooperative housing by using both qualitative and quantitative research methods, and the findings indicated that cooperative living helped the rural elderly to extend independent living and stay in touch with their familiar community. The studies illustrated that cooperative housing stimulates aging in place for the elderly in the rural dimension.

\section{METHOD}

To achieve the specified goals of this study, field research was adopted, and such qualitative research methods as site visits, observation, and individual interviews with the board of directors were employed before the focus group interviews with a group of residents was administered. With a full list of housing cooperatives in rural Midwest, all the senior housing cooperatives in the rural areas were located and contacted. In cooperation with managers and the board of directors, some residents in each senior coop housing who could voluntarily participated in the focus group were

\footnotetext{
${ }^{1}$ Due to the nature of a business form, senior housing cooperatives aren't easily recognized only with physical features, and they provide congregate services. In a true sense, 92 housing cooperatives for the elderly or so have been supplied in 10 states of the U.S. since the first senior housing cooperative was built in 1978 (McKinley, 2005). Out of them, 83 housing cooperatives are located in either Minnesota or Iowa, and more than half of them (44) are in rural areas.
}

recruited. The four rural small towns in Minnesota and Iowa were chosen where cooperative housing for the elderly was developed and most importantly, voluntary participation in and cooperation with the research were considered - Springfield in Minnesota, and Hull, Estherville, and Spirit Lake in Iowa. All of the four studied communities were typical rural towns that were smallsized but vibrant. In a series of focus group interviews taking place in each cooperative housing, 40 residents in total participated; 9 in Springfield, 9 in Estherville, 16 in Hull, and 6 in Spirit Lake).

Before the focus group, all the four communities were visited and the research background and procedure were explained to the stakeholders. With full cooperation at a community level, every focus group was conducted by a team of three researchers experiencing qualitative research studies on the elderly, and all the participants across the developments were asked with questions (e.g., reasons for moving in current cooperative housing, satisfaction with current communal living, strengths and weaknesses of cooperative living) based on Althus and Matthews (1997), Nolan (1997). Each question was structured with categories laid out in elements. Each discussion conducted on site was carefully recorded and the content was transcribed into text files. All the four transcripts drawn up were crosschecked and reviewed among researchers and gerontologists in preparation for transcript analysis. Then, the transcripts were analyzed according to the research purposes. The procedures for focus group interviews followed guidelines recommended by some references (Krueger \& Macey, 2000; Kvale, 1996; Seidman, 2006; Strauss \& Corbin, 2007).

\section{RESULTS}

\section{(1) Description of the Studied Housing Cooperatives and their Participants}

The studied rural communities were recognized as sustainable and shared similar community features (e.g., smallsized, agriculturebased towns, modest economic growth, strong cohesion, traditional family values, and increase in the number of the elderly). They all had experienced not just the strong demand for senior housing but a shortage of affordable housing for young families. The four housing cooperatives were relatively small in the number of units (from 16 to 26), and the units were designed for one and twobedroom suited to couple or single elderly (Table 1).

The four selected cooperatives required people who are expected to be a principal resident to be aged over 55 , but the cooperatives tended to be feminized and aged (Table 2). Out of 40 participants, the average age was about 74 years old, and the youngest was 62 in Spirit Lake while the oldest was 87 in Hull. The average age of the participants by housing cooperatives was 69 years old in Springfield, 72 in Estherville, 79 in Hull and 69 in Spirit Lake, so the housing cooperative in Hull was the oldest community while the Springfield and Spirit Lake were relatively younger. With the age cohort, the vast majority of the participants were in either the youngold group ranging from 65 to 74 years old $(47.5 \%)$ or the midold group from 75 to 84 years old $(42.5 \%)$. Only two participants were

in the old-old group ( 85 years and older) while another two were less than 65 years old. All the participants were Caucasian, so all the four housing cooperatives were ethnically homogenous.

As the aging process is advanced, the female elderly are likely to be dominant. The gender distribution of the participant was 
Table 1. Description of the Studied Housing Cooperatives in Rural Communities

\begin{tabular}{|c|c|c|c|c|c|}
\hline City Name & $\begin{array}{l}\text { Studied } \\
\text { housing }\end{array}$ & $\begin{array}{l}\text { No. of } \\
\text { Units }\end{array}$ & $\begin{array}{l}\text { Unit } \\
\text { types }\end{array}$ & $\begin{array}{l}\text { Unit size } \\
\left(\mathrm{m}^{2}\right)\end{array}$ & $\begin{array}{l}\text { Year } \\
\text { built }\end{array}$ \\
\hline Springfield & & 19 & 8 & $\begin{array}{c}198.12 \\
\text { to } \\
332.84\end{array}$ & 1995 \\
\hline Estherville & & 26 & 2 & $\begin{array}{c}206.04 \\
\quad \text { to } \\
285.29\end{array}$ & 1996 \\
\hline Hull & 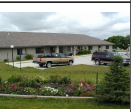 & 16 & 2 & $\begin{array}{c}206.04 \\
\quad \text { to } \\
324.92\end{array}$ & 1995 \\
\hline Spirit Lake & $\sqrt{3}=$ & 25 & 6 & $\begin{array}{c}206.04 \\
\text { to } \\
332.84\end{array}$ & 1996 \\
\hline
\end{tabular}

Note. All the housing estates were one-story building, their minimum age was 55 years old, and bedroom styles available were either one- or two-bedroom styles. consistent with it; the vast majority of the participants were female $(80 \%)$, and only 8 were male (20\%). All male participants but one resided in Iowa while half of them were married. The average age of the male participants was 71 . As for the marital status, the great majority of the participants were widowed (60\%), and less than one third were married (30\%). Four participants lived alone (10\%) for the reasons of separation, divorce and no marriage in life. The highest concentration of the widowed was found in Hull where participants in the old-old group were dominant, and only two participants in the community were married.

Less than half of the participants seemed to have no professional job $(43 \%)$, and slightly more than one third of the participants in Hull were cited as housewives (69\%). It seemed that participants serving the board or committees used to have sort of job experience in the past. With regard to the positions in the housing cooperatives, more than half of the participants sat on either the board of directors or steering committee members (58\%). A couple of the participants serving officers in Hull had their sons on the

Table 2. Description of the Participants in the Studied Four Housing Cooperatives

\begin{tabular}{|c|c|c|c|c|c|c|c|}
\hline Community & Participant & Age & Gender & Marital status & Previous occupation & $\begin{array}{l}\text { Position in } \\
\text { Cooperative }\end{array}$ & Note \\
\hline \multirow[t]{9}{*}{ Springfield (9) } & 1 & 75 & Female & Widowed & Housewife & Member & \multirow{9}{*}{$\begin{array}{l}\text { Served on interim board } \\
\text { Husband in a nursing home }\end{array}$} \\
\hline & 2 & 65 & Female & Widowed & Housewife & Committee member & \\
\hline & 3 & 68 & Female & Married & Administrator & Officer & \\
\hline & 4 & 78 & Female & Widowed & Nurse & Member & \\
\hline & 5 & 63 & Female & Never married & School teacher & Committee member & \\
\hline & 6 & 70 & Male & Widowed & Farmer & Officer & \\
\hline & 7 & 65 & Female & Married & Accountant & Officer & \\
\hline & 8 & 71 & Female & Separated & Housewife & Member & \\
\hline & 9 & 67 & Female & Married & Small business owner & Committee member & \\
\hline \multirow[t]{9}{*}{ Estherville (9) } & 10 & 65 & Female & Married & Realtor & Member & \multirow{9}{*}{$\begin{array}{l}\text { Served on interim board } \\
\text { Snow bird }\end{array}$} \\
\hline & 11 & 69 & Male & Married & Small business owner & Officer & \\
\hline & 12 & 73 & Male & Widowed & Farmer & Officer & \\
\hline & 13 & 70 & Female & Widowed & School teacher & Member & \\
\hline & 14 & 78 & Female & Widowed & Banker & Committee member & \\
\hline & 15 & 72 & Female & Widowed & Housewife & Member & \\
\hline & 16 & 68 & Male & Married & Businessman & Officer & \\
\hline & 17 & 83 & Female & Widowed & Housewife & Member & \\
\hline & 18 & 67 & Female & Married & Administrator & Committee member & \\
\hline \multirow[t]{16}{*}{ Hull (16) } & 19 & 87 & Female & Widowed & Housewife & Member & \multirow{16}{*}{ Son serving on the board } \\
\hline & 20 & 82 & Female & Widowed & Housewife & Member & \\
\hline & 21 & 79 & Female & Widowed & Housewife & Committee member & \\
\hline & 22 & 84 & Female & Widowed & Housewife & Officer & \\
\hline & 23 & 78 & Female & Widowed & Housewife & Member & \\
\hline & 24 & 82 & Female & Widowed & Secretary & Committee member & \\
\hline & 25 & 78 & Female & Widowed & Housewife & Member & \\
\hline & 26 & 74 & Female & Widowed & School teacher & Committee member & \\
\hline & 27 & 77 & Male & Widowed & Farmer & Officer & \\
\hline & 28 & 86 & Female & Widowed & Housewife & Officer & \\
\hline & 29 & 76 & Female & Widowed & Housewife & Member & \\
\hline & 30 & 82 & Female & Widowed & Housewife & Member & \\
\hline & 31 & 75 & Male & Married & Farmer & Committee member & \\
\hline & 32 & 72 & Female & Married & Administrator & Member & \\
\hline & 33 & 76 & Female & Widowed & Housewife & Officer & \\
\hline & 34 & 83 & Female & Widowed & Housewife & Committee member & \\
\hline \multirow[t]{6}{*}{ Spirit Lake (6) } & 35 & 66 & Female & Never married & Small business owner & Officer & \multirow{6}{*}{$\begin{array}{l}\text { Served on interim board } \\
\text { Snow bird } \\
\text { Served on interim board }\end{array}$} \\
\hline & 36 & 62 & Female & Married & Kindergarten teacher & Member & \\
\hline & 37 & 75 & Female & Widowed & Secretary & Member & \\
\hline & 38 & 74 & Male & Married & Farmer & Officer & \\
\hline & 39 & 65 & Male & Divorced & Realtor & Committee member & \\
\hline & 40 & 72 & Female & Married & Housewife & Member & \\
\hline
\end{tabular}


board, so that they were able to take care of the duties on behalf of them. Although some of the participants were very old, all of them mentioned that they were healthy enough to have no problems in daily life.

\section{(2) Reasons to Move in Housing Cooperatives}

The forty participants were asked about why they chose current housing, and most of them mentioned either maintaining independent life or carefree living (Table 3). That is, the participants would like to plan ahead for housing in later life.

Table 3. Summary of Reasons for Moving in Current Housing

\begin{tabular}{l|c}
\hline \multicolumn{1}{c|}{ Items } & $\mathrm{f}(\%)$ \\
\hline Maintaining independent life & $14(35.0)$ \\
Care-free living & $12(30.0)$ \\
Safe housing & $6(15.0)$ \\
Affordable housing & $5(12.5)$ \\
Others & $3(7.5)$ \\
\hline \multicolumn{1}{c|}{ Total } & $40(100.00)$ \\
\hline
\end{tabular}

Note. Others include living close to children, involuntary relocation of spouse, and seasonal home

All of the participants said that much of their life was spent in single family home, and living in a housing cooperative was quite a new experience they had never had before. Given the facts that rural people are selfindependent and take living in a single family home for granted, and multifamily housing is scarce in rural areas, a housing cooperative was experimental and the living could be challenging. All of the participants said that they lived in single family home before moving in, and indeed, they were born and spent most of the time in single family home. Thus, the life in the housing cooperative was different and required them to have a new adjustment since the communal living changed many aspects of their lifestyle.

\footnotetext{
"it's kind of, kind of extended family after all" (Springfield)

"(The cooperative housing) takes care of anything, you know, the outside and maybe inside. I was on a farm, I had to walk a quarter of mile to get on a driveway." (Estherville)

"it's operated efficiently because no profit margins... anybody and we're operating just (at) cost." (Hull)

"One thing is (that) you can own your home which you don't have to take care of some most maintains... You don't have to worry about shoveling snow when it's snowing... You don't have to worry about roofing going off when wind blows. " (Spirit Lake)
}

Many of the participants pointed out that one of the main reasons to choose the housing cooperative was to think and plan ahead. They emphasized that downsizing and moving in later life were not an option and it's better to move earlier than later because it cost far more in the last stage of the life. Most of the participants stressed that when they got older, they were forced to move in a larger city where medical care services were available but it's not easy for them to do so. Although frailty was inevitable and predictable, they wanted to stay in the community where they had lived for a long time, and to see the people with whom they had been familiar. Nursing home or assisted living was the housing for the independent elderly in the town, and they were not ready to move in. Also, apartment did not meet their lifestyle. In fact, there had been no independent living arrangement for the elderly in such small rural communities, so that the housing cooperative was right for them.

"For me, I lived in a big house (with a) great big attic and I lived there 50 years. ..And I worked all the time... and (I) come home, and do yard work, and to anything like that. I have to have an easier lifestyle. And I was waiting for something to be built because I didn't want to rent an apartment absolutely." (Springfield)

"Steps get steeper when you get older." (Estherville)

"I think that younger move out here, the more you get use of money that you invest. I mean, if you wait until your probably in your late, real later years, it's gonna cost you more." (Hull)

"We're an independent place... independent living, being independent as long as you can." (Spirit Lake)

Many of the participants who were widowed mentioned that keeping up single family home was cumbersome, especially without the husband who used to be in charge of doing so. After their husband passed away, the participants wanted to easily maintain a house without losing homeownership. Homeownership was another key factor affecting the decision to move. Owning a home was familiar for the participants, and they were attracted to the cooperative in that it kept a sense of homeownership. Besides, the widowed participants were concerned about security and safety. They realized that secured and safe housing was needed, and also it's not easy for them to go up and down in a house in which they had been living for a long time.

One participant living alone mentioned that her living status was not voluntary because her husband was so sick to be relocated in a nursing home. The house without husband was too large for her to maintain, and then she considered moving. Her husband was in the nursing home of the town and she did not want to leave the town. Then, she looked for communal living, but did not want to live in an apartment. She mentioned that a friend of hers living in an apartment felt somewhat threatening because many in the apartment were either young or lowincome people so their lifestyle was hard for the elderly to tolerate (e.g., noise and privacy).

Also, two of the participants described themselves as snow birds, and owned another house close to their children out of the state. After retirement and husband's passing, one participant seriously thought of moving and living close to her children. However, she born, grew up and wanted to spend the rest of her life and to be buried in the hometown, which she said was very natural. With the wish, she decided to buy another house nearby their children's, and it was a condominium. Also, she bought shares of a housing cooperative in her hometown. She spent spring and summer in their hometowns while being with their children in fall and winter. One of the advantages of being a snow bird she said was to get away 
from the cold winter. Also, she stated that it's a good experience to live in two different kinds of housing, and living in a housing cooperative was a lot better than in a condominium (e.g., having a say on how the cooperative runs it, companionship, carefree living and the like). The other participant mentioned that much of her adult life was spent in another state, and her children settled down there. While being distant from her hometown, she did miss her friends and families in hometown, and heard of the development in one of her recent visits. As she would like to spend some time in the hometown and she was familiar with the group living, she easily made a decision to move in the housing cooperative. She found it handy to live in the cooperative.

"I lost my spouse before moving...I'm glad I'm here... My family all live away. I didn't wanna leave, you know, and everybody I knew (has) been with (me for) so many years. And I couldn't visualize going to live where my daughters live because I wanna live in a place where I (have) been knowing, you know." (Estherville) "I was in a condominium before I came here. I still have to hire people to come out and fix the garage door, to do this, to do that. You still have to maintain working part, you know Individual part, your unit.“ (Spirit Lake)

\section{(3) Residential Assessment on Communal Living}

When all the participants were asked to evaluate the current living, they all expressed high satisfaction with living in such communal living, and all were willing to recommend the living to friends or others (Table 4). Indeed, almost all the participants were proud of living in the housing.

Table 4. Summary of Residential Assessment on Communal Living

\begin{tabular}{lc|c}
\hline \multicolumn{2}{c|}{ Items } & $\mathrm{f}(\%)$ \\
\hline Very satisfied & & $25(62.5)$ \\
Satisfied & $15(37.5)$ \\
\hline \multicolumn{2}{c|}{ Total } & $40(100.00)$ \\
\hline
\end{tabular}

Although they mentioned some advantages and disadvantages of communal living, the most commonly cited feature the participants liked was elderlyfriendly design (Table 5). Barrierfree design, or socalled universal design, features were applied to both individual units and the entire building not only to support the independent living of the elderly but also to enable them to continue to independently live in response to the changing physical needs. The specific examples included no thresholds or no stairs between spaces and in the building, pushup faucets in kitchen and bathroom, grab bars around the bathtub, light switches with large flat panels, lever handles in opening doors, wide interior doors and hallways, handrails in corridors, and the like.

"I couldn't live here independently...(because) I had basement, steps, and things like that...I have 27 downstairs." (Springfield)

"A small house to take care of...Security... I think it's done on flat level, no up and down stairs almost." (Estherville)

"I like it because all is onefloor. No steps. Oh, there are lots of things I like." (Hull)

"That's quiet and our location couldn't be beat, close to the hospital, that clinic, that senior center, uptown is only in few minutes. I don't know how we couldn't be even better." (Spirit Lake)

Table 5. Summary of Reasons for Residential Satisfaction with Communal Living

\begin{tabular}{l|c}
\hline \multicolumn{1}{c|}{ Items } & $\mathrm{f}(\%)$ \\
\hline Elderly-friendly design & $19(47.5)$ \\
Building safety and security & $11(27.5)$ \\
Supportive services & $6(10.0)$ \\
Others & $4(10.0)$ \\
\hline \multicolumn{1}{c|}{ Total } & $40(100.00)$ \\
\hline
\end{tabular}

Note. Others include companionship, common spaces, and community activities

Also, the controlled access to main entrance of the building was another feature participants liked. Since most of the residents in each housing cooperative were female and windowed and the elderly were sensitive to personal safety, the feature gave the residents a sense of protection. Another feature participants liked was gardens that were available and easily accessible. Some of garden plots were connected to patio of individual units, and the layout brought about more pleasant gardening to residents. Moreover, it was not easy for the elderly to shovel snows on a car windshield and to drive a car in winter, so it was reported that the indoor garage was useful and got rid of the hassles. For those who would like to go to see a doctor, get some medicines or to make some trips for shopping or banking, mini van was available, and the service was helpful. Another feature with which the participants were satisfied was guest room available. In small towns, motels or lodging services were not easily ready, and the expense was not cheap. For the residents who had children out of state or visitors, the room was available upon the reservation that was made on a firstcome, firstserved basis, and the fees were very reasonable. Many reported that the service was great in that the elderly residents stayed together with the visitors under one roof. In addition, it was said that inside mailboxes helped the residents easily to pick up mails regardless of weather outside. The participants mentioned that almost everything could be done without going out.

"I came up with my family, fine, a bigger dining room, you got a home, and now you can tell what. They're gonna stay overnight. Fine. We got a guest room for you. Use a guest room. I got much stuff to get rid of. Fine. We got a storage room, too. Each room gets its own storage room." (Springfield)

"I felt isolated in a singlefamily home." (Estherville)

"And another thing that is really an advantage to us is (to) have a van." (Hull)

"you have a sense of security that you can freely walk 
up and down the hall every time, day or night, without fear of running into someone that isn't welcome here." (Spirit Lake)

One important feature many of the participants liked was companionship among residents. Most of the residents were in similar age cohorts, and the fact helped them to share common interests. Also, some rooms were available for the specific purposes such as community room, exercise room, workshop, sunroom and library. The participants enjoyed the spaces; group activities (e.g., card making, crafts, quilting, bingo, and watching TV) were popular and arranged in those rooms. The rooms easily invited residents whenever they wanted to get involved in any. That is to say, those places led to social encounters.

"safety, management....companionship, security... homeownership..." (Springfield)

"We probably have more activities here than now... we got the common rooms, so we can use them all." (Estherville)

"All we have to do is reserve common or any place else you want, we got other places, too, in the area... Birthday party, families come. And we can be (in) socials we want and we can invite people here." (Hull) "And here we probably have more gettogether, more coffee, more play cards, and things like that... because we can't get out, going place but we still have companionship.“(Spirit Lake)

In spite of all the advantages the participants cited, some of the disadvantages were stated (Table 6). Privacy used to be one of the concerns participants had, but they learned that it was instantly solved leaving the main door of a unit open meant a good signal for residents to allow neighbors to come in and visit. If the residents would not be disturbed, they kept their privacy by simply closing the door. The nonverbal ways assured privacy. Some participants said that they wanted more spaces for their personal belongings even though individual storage rooms and walkin closets in each unit were available. Since they lived in a single family home where ample spaces afforded to keep all, it was very challenging for them living in singlefamily home to throw away personal stuff of which every piece had a special memory. Another complaint was soundproofing. As the weak auditory sense led the elderly residents to turn up the TV, it's so loud to be annoying. The noise could be heard in next door or hallway. Some participants pointed out better soundproofing finishes in the entire building.

Table 6. Summary of Reasons for Residential Dissatisfaction with Communal Living

\begin{tabular}{lc|c}
\hline \multicolumn{1}{c|}{ Items } & $\mathrm{f}(\%)$ \\
\hline Lack of privacy & $19(47.5)$ \\
Storage spaces & $11(27.5)$ \\
Noise & $6(10.0)$ \\
Others & $4(10.0)$ \\
\hline \multicolumn{2}{c|}{ Total } & $40(100.00)$ \\
\hline
\end{tabular}

Note. Others include decoration or specific interior design considerations

\section{(4) Strengths and Weaknesses of Housing Cooperatives}

Living in a housing cooperative was new for almost all the participants, and many of the participants were asked about pros and cons of the living along with what could have done better. The participants regarded homeownership as very important. The best known feature of cooperative housing was participation of residents who are users and members, and the participatory nature seemed to give elderly residents a sense of control over the property. Some of the participants liked overseeing how the cooperative run, and also it's nice to have a say on the operation through a manager's regular report. In other words, the management of the cooperative is controlled by residents. Another benefit of living in the cooperative mentioned was no profitable behaviors that occurred, and all the expenses were reasonable.

"It's nice to be able to tell everybody freedom to express." (Springfield)

"We're a function on the board, I mean, what to do it, (is to) still keep day operation." (Estherville)

"we do have committees, so we try to get everybody involved in our committees, so they're involved in some (activities)..." (Hull)

"We are the coop..(it) was able to maintain...more affordable price for the seniors " (Spirit Lake)

Some of the touchup activities in a unit should be approved by the board. For example, a resident was required to get redemption from the board if any costs incurring in an individual unit would be reimbursed or reflected in the value of shares. Therefore, valueadded behaviors at a personal level took place according to the policies set by the cooperative, and the expense could be accrued in the share value and redeemed at the time of moving out. Also, since all the charges were either nominal or reasonable, the monthly fees including electricity, water, snow removal, lawn care, cable TV, but phone bill were low and could be simply paid in one check. The low cost service and simple payment were regarded as another benefit of living in a housing cooperative the participants mentioned.

"...everything is paid for but your telephone. So, you don't have to be writing out checks." (Springfield)

"Once you're in there, it's, we could like living a house, at home over the period, and it says cheaper here because everything is included - your fees, taxes, insurance, and everything." (Estherville)

Also, the cooperative provided the service of marketing and transacting a unit if the residents would like to move out. Many participants described that they were very familiar with numerous behaviors taking care of single family home that required a lot of physical efforts and labor work shoveling snow in winter, mowing the lawns in summer, roofing, painting, and all the repairs or maintenance. Management staff took care of these, and even fixing a small sink faucet could be easily done just by giving one phone call to the management office. Many said that the convenience would have never imagined before moving in.

“... when I go away for a week or few days, and I don't have to worry about anything. That's a lot to me.” (Springfield) 
"Free to travel when you want. I have to lock the door, and when you're gone you don't have to worry, you know, that anything shouldn't go wrong or something, why, you know, maintenance people that you have your keys that they can get in there, you know, when we're up here alarm going off or something that he would be able to slip in there or check to be sure that everything is okay." (Spirit Lake)

Equality was important to implement all the policies, and following the policies was critical in each community even though the policies were reviewed on a regular basis and sometimes revised. As democracy was a key factor in making the operation of a cooperative successfully, some minor opinions would not be adopted or accepted, and certain kinds of personal lifestyles were often disregarded. For instance, pets like dogs, cats or birds were not allowed, and some residents should put up with the pet policy. Other than officers or committee members, ordinary members might not be aware of the policies if any change was made. Participants agreed to place high emphasis on the way to keep the members to be informed, so the continued education among members was accented.

"I think it's so bad you can't put up with it. We have a meeting and try to leave on board meetings" (Springfield)

"Almost everybody (here) is involved in some committee...It's important (for all) to know what's going on here." (Estherville)

"We have the monthly board meeting all homeowners attend. In that way, we are informed." (Hull)

"They can come and voice, you know, what they have to say something, and always they're welcomed (with) those. And we, had people involved on the committees, they would like to serve, you know, maybe just count ballots at our annual meeting or to be on the nominating committee, or budget committee, just a shortterm." (Spirit Lake)

Some of the participants served on the interim board during the development process of a housing cooperative, and pointed out one barrier to the housing cooperative a public perception on senior housing. It was a notion that senior housing in town was for the elderly who were very frail and debilitated. The reason was partly attributed to no independent living arrangement available in each town, and the housing alternative available was either nursing home or assisted living. The circumstance led people to unfamiliarity with cooperative housing for the independent elderly, and further lack of the awareness caused a difficulty in recruiting prospective residents at the initial stage of the cooperative development. Even after the housing cooperative was completed and run very well, there was still misconception that the housing cooperative was another form of nursing home. Interestingly enough, each housing cooperative maintained a wait list, and anyone coming in the housing was impressed with the quality of life.

Based on the responses of participants aforementioned, the strengths and weaknesses of housing cooperatives can be summarized in Table 7.
Table 7. Summary of Strengths and Weaknesses of Housing Cooperatives

\begin{tabular}{l|c}
\multicolumn{1}{c|}{ Items } & $\mathrm{f}(\%)$ \\
\hline Strengths & $27(67.5)$ \\
Homeownership & $6(15.0)$ \\
Control over the property and management & $4(10.0)$ \\
Not-for-profit taking & $3(7.5)$ \\
Democratic operation & $40(100.00)$ \\
\hline \multicolumn{1}{c|}{ Total } & $15(37.5)$ \\
Weaknesses & $13(32.5)$ \\
Lack of awareness & $11(27.5)$ \\
Unfamiliarity & $1(2.5)$ \\
Public misconception & $40(100.00)$ \\
Other & Total \\
\hline
\end{tabular}

Note. Other includes dissenting voices suppressed in decision-making

\section{CONCLUSIONS}

As the housing market tightens and decent and affordable housing declines, the importance of community sustainability grows and the interest in housing cooperatives rises. As a competitive yardstick, housing cooperatives are considered as a housing alternative playing a key role in sustaining a community and serving the growing population with special needs. Most of the rural areas that make efforts to make their communities sustainable have witnessed the growing number of the elderly, and the issue of addressing their housing need becomes a pivotal concern. This study investigated residential life of rural elderly living in housing cooperatives of sustainable communities. The specific goals included factors driving the decision of rural elderly to move in housing cooperatives, residential assessment, and pros and cons of cooperative living. With the use of qualitative research methods, this study conducted indepth focus group interviews with 40 elderly persons in the four housing cooperatives.

Firstly, the finding indicated that the main factor affecting the decision of the elderly participants to move in was the need for a supportive environment enabling them to continue independent living. Before physical frailty comes outstanding, downsizing and efficient living were necessary, and the readiness was possibly made; they believed that earlier would be better than later. The notion of planning ahead led them to move in communal living that provides carefree living and many conveniences, and the consequence brought about freedom that trades time to take care of a house. It seemed that loss of spouse played a leading part in the decisionmaking.

Secondly, all the participants were satisfied with living in the housing cooperatives, and they favored such physical features as elderlyfriendly design, controlled access, indoor garage, common spaces, social activities, garden, and mini van. Almost all of the participants used to live in single family home, and they found it somewhat difficult to manage their personal belongings in limited spaces. Also, psychological features were illustrated a sense of safety and security and companionship. In fact, the participatory nature of housing cooperatives allows the elderly to remain in control over the property and its management (Lee, 2003, 2004, 2007, 2010a, 2010b). The fact had a positive effect on the assessment of the participant. 
Thirdly, despite benefits of communal living and strengths of cooperative living, the participants mentioned that most of the rural people mistakenly considered the independent living arrangement as a setting specially designed for the elderly who are physically feeble like nursing home. Also, they strongly believed that the idea of independent living arrangement suits the need of rural elderly who are predominantly selfindependent since there had never been sorts of independent living arrangements in rural towns.

The research results imply that cooperative housing serves a housing alternative that keeps rural communities sustainable and continues aging in place of the rural elderly. In other words, the type of housing can be meaningful in the quality of the elderly's life, and the provision is critical to keep them in the community and further to affect its sustainability. Often many components in dealing with the elderly are taken into considerations, and medical care services and economic resources among them are highly emphasized. Nonetheless, the supply of decent and affordable housing for the elderly is so grave in continuing their independent living that the issue should be centered on the policy agenda for the group.

The implications are extended to Korea, where the depopulation in rural communities continues and the assets and resources to maintain community sustainability aren't easily acquired. The bottomup approach to a unique and local solution for affordable elderly housing can be applied and explored; the needs of the elderly people for affordable housing should be addressed and examined at a local level, and then the provision is primarily led by local people and utilized with local resources. Also, the housing governance and its operation mechanism that are unfamiliar to Korea address that the application of cooperative housing would be challenging unless the principles of the idea are adequately delivered to residents/ users/ members with various mediums.

\section{REFERENCES}

Altus, D.E., \& Mathews, R.M. (1997). A look at the satisfaction of rural seniors with cooperative housing. 1997 Cooperative Housing Journal, 10-16.

Bratt, R.G. (1991) "Mutual housing: Communitybased empowerment." Journal of Housing, 48(4), 173-180.

Cobia, D.W. (1989). Cooperatives in agriculture. Englewood Cliffs, New Jersey: Prentice Hall, Inc.

Dolbeare, C.N. (1999). Conditions and trends in rural housing. In J.N. Belden \& R.J. Wiener (Eds.), Housing in rural America (pp. 13-26).

Ellenbecker, J.H. \& White, B.J. (1987). Housing cooperative resident motivations and perceptions: A Colorado housing cooperative study. 1985 Cooperative Housing Journal, 8-16.

Frederick, D.A. (1997). Coops 101: An introduction to cooperatives. Washington, DC: United States Department of Agriculture, Rural Business - Cooperative Service, Cooperative Information Report 55.

Frederick, D.A. (1999). Understanding cooperatives: Legal foundations of a cooperative. Washington, DC: United States Department of Agriculture, Rural Business - Cooperative Service, Cooperative Information Report 45, Section 9.

Heskin, A.D. (1991). The struggle for community. Boulder, CO: Westview Press.
Heskin, A.D., \& Leavitt, J. (1995). The hidden history of housing cooperatives. Davis, CA: Center for Cooperatives, the University of California-Davis.

Kennedy, T., Jermolowicz, A., Lambert, M. A., Reilly, J., \& Rotan, B. (1995). Cooperatives: A housing alternative for rural America. Washington, DC: U.S. Department of Agriculture, Rural Business and Cooperative Development Service.

Krueger, R.A. \& Casey, M.A. (2000). Focus groups: A practical guide for applied research (3rd Ed.). Thousand Oaks, CA: Sage Publications, Inc.

Kvale, S. (1996). InterViews: An introduction to qualitative research interviewing. Thousand Oaks, CA: Sage Publications, Inc.

Leavitt, J. \& Saegert, S. (1990). From abandonment to hope: Communityhouseholds in Harlem. New York: Columbia University Press.

Lee, H. (2003). "Environmental support of independent elderly households in senior coop housing." Journal of the Korean Housing Association, 14(5), 57-64.

Lee, H. (2004). "Provision of affordable housing for urban seniors in a global era." Architectural Research, 6(2), 1-9.

Lee, H. (2007). "Residential mobility of the elderly for independent living." Architectural Research, 9(2), 1-9.

Lee, H. (2010a). "Keeping a community sustainable: Development of affordable housing for the elderly in nonmetropolitan areas." Architectural Research, 12(2), 63-72.

Lee, H. (2010b). "Residential satisfaction of the elderly in cooperatively owned housing and rental housing." Architectural Research, 12(2), 73-83.

McKinley, T.W. (2005). Senior cooperative housing: A shift in perception. Minneapolis, MN: Senior Cooperative Network.

Meyer, T.M. (1994). Understanding cooperatives: The American system of business. Washington, DC: USDA, Rural Development Administration, Rural Business-Cooperative Service, Cooperative Information Report 45, Section 1.

Meyer, T.M. (1999). Understanding cooperatives: Cooperative business principles. Washington, DC: USDA, Rural Development Administration, Rural Business-Cooperative Services, Cooperative Information Report 45, Section 2.

Miceli, T.J., Sazama, G.W. \& Sirmans, C.F. (1994). "The role of limitedequity cooperatives in providing affordable housing." Housing Policy Debate, 5(4), 469-90.

National Cooperative Business Association (2008). Coop statistics. Available on http://www.ncba.coop/abcoop_stats.cfm

Nolan, J.E. (1997). Examination of the quality of life among older adults living in rural cooperative housing. Doctoral dissertation, The Ohio State University.

Parliament, C. (2000). Cooperatives and agribusiness organization. St. Paul, MN: University of Minnesota, Department of Applied Economics, Lecture Note.

Parliament, C., Vonnegut, A., \& Parliament, S. (1998). "Keeping housing affordable: cooperative vs. absentee ownership." 1998 Cooperative Housing Journal, 18-24.

Rohe, W.M. (1995). "Converting public housing to cooperatives: The experience of three developments." Housing Policy Debate, 6(2), 439-79.

Saegert, S. \& Winkel, G. (1996). "Paths to community empowerment: Organizing at home." American Journal of Community Psychology, 24(4), 517-50. 
Saegert, S. \& Winkel, G.. (2001). Cooperative housing, social capital and crime prevention. 2001 Cooperative Housing Journal, 13.19 .

Seidman, I. (2006). Interviewing as qualitative research: A guide for researchers in education and the social sciences. New York: Teachers College Press.

Strauss, A. \& Corbin, J.C. (2007). Basics of qualitative research: Techniques and procedures for developing grounded theory (3rd Ed.). Thousand Oaks, CA: Sage Publications, Inc.

US Dept. of Agriculture, Agricultural Cooperative Service (1993a). Cooperatives in agribusiness. USDA, Agricultural Cooperative Service, Cooperative Information Report 5.

US Dept. of Agriculture, Agricultural Cooperative Service (1993b). Cooperative organization and structure. US-DA, Agricultural Cooperative Service, Farmer Cooperatives in the U.S. Cooperative Information Report 1, Section 6.

US Dept. of Agriculture, Rural Business and Cooperative Development Service (1995). Cooperative financing and taxation. USDA, Rural Business and Cooperative Development Service, Farmer Cooperatives in the U.S., Cooperative Information Report 1, Section 9.

US Dept. of Agriculture, Rural Business - Cooperative Service (1996). Cooperative housing for rural America. USDA, Rural Business - Cooperative Service, Cooperative Information Report 53.

van Ryzin, G.G. (1992). "How participating management can benefit cooperative residents.” 1992 Cooperative Housing Journal, 11-14.

van Ryzin, G.G. (1994). "Residents' sense of control and ownership in a mutual housing association." Journal of Urban Affairs, 16(3), 241-253.

Zimmer, J.E. (1977). From rental to cooperative: Improving low and moderate income housing. Beverly Hills, CA: Sage Publications, Inc.

(Date of Submission : 2010.1.14) 